\title{
Perbandingan Biaya Struktur Akibat Alternatif Pondasi dengan Meninjau Interaksi Struktur-Tanah Dasar Studi Kasus Gedung A Teknik Sipil FTSP ITS
}

\author{
Mohamad Khoiri \\ Staff pengajar D3 Teknik Sipil FTSP ITS \\ Email: mkhoiri@ce.its.ac.id
}

\begin{abstract}
ABSTRAK
Gedung A Teknik Sipil ITS adalah gedung dengan denah yang sederhana, simetris, dan tipikal. Lokasi gedung tersebut berada disebelah Rektorat ITS dengan kondisi tanah dasar adalah tanah lunak dengan kedalaman $\pm 16 \mathrm{~m}$. Sesuai dengan kondisi tersebut perencana biasanya memilih pondasi tiang pancang atau pondasi mat sebagai struktur bawahnya. Untuk memikul beban struktur pada sebuah titik Kolom perencana dapat membuat variasi kedalaman tiang pancang dan jumlahnya. Perencana dapat memilih kedalaman yang kecil dengan jumlah tiang yang banyak atau sebaliknya. Dalam hal ini variasi kedalaman group tiang pancang yang dipilih untuk perbandingan adalah $6 \mathrm{~m}, 9 \mathrm{~m}, 12 \mathrm{~m}$ dan $16 \mathrm{~m}$. Jadi akan dibedakan 5 jenis pondasi yaitu pondasi mat dan 4 variasi pondasi tiang pancang, dan dicari sejauh mana perbedaan biaya pondasi dan biaya sturktur akibat adanya perbedaan penulangan struktur sebagai konsekuensi dari jenis pondasinya. Pemilihan jenis pondasi yang berbeda diatas akan memberikan penurunan yang berbeda pada titik perletakannya. Sedangkan penurunan dapat menyebabkan perubahan pada gaya dalam struktur atas. Demikian pula dimensi balok dan kolom pada struktur atas akan berbeda. Dengan cara interaksi struktur atas dan struktur bawah, perbedaan penurunan dan gaya dalam pada masingmasing struktur tersebut dapat diketahui dan dimensi serta penulangan balok dan kolom dapat direncanakan. Interaksi ini dihitung dengan menganggap struktur atas bertumpu pada pegas. Koefisien pegas diperoleh berdasarkan perumusan $\mathrm{P}=$ k. $\Delta$. Dimana $\Delta$ adalah penurunan akibat konsolidasi. Perhitungan yang telah dilakukan menunjukkan bahwa struktur dengan pondasi mat memberikan total biaya paling ekonomis. Selanjutnya diikuti dengan struktur dengan pondasi group tiang pancang $16 \mathrm{~m}, 12 \mathrm{~m}$, dan $9 \mathrm{~m}$. Sedangkan pondasi tiang dengan kedalaman 6m tidak bisa dilaksanakan karena daya dukung ijinnya terlalu kecil sehingga jumlahtiang yang dibutuhkan terlalu banyak. Untuk struktur dengan pondasi group tiang pancang yang dipancang sampai tanah keras $(24 \mathrm{~m})$--tidak akan ada deformasi pada pondasi-- menghasilkan total biaya lebih murah dari group tiang pancang $16 \mathrm{~m}$, akan tetapi tetap lebih mahal dari struktur dengan pondasi mat. Kata kunci: Pondasi, Penurunan, Soil-Struktur Interaction
\end{abstract}

\section{PENDAHULUAN}

1.1. Latar Belakang

Gedung A Teknik Sipil ITS gedung yang dibangun sebagai tempat perkuliahan yang baru bagi mahasiswa jurusan teknik Sipil ITS. Gedung ini mempunyai denah yang sederhana, simetris, dan tipikal, yang terdiri dari lantai dasar dan 2 lantai diatasnya. Lokasi gedung tersebut berada di sebelah gedung rektorat ITS, dengan kondisi tanah adalah tanah lunak dengan kedalaman \pm 16 m.

Berdasarkan kondisi diatas, biasanya perencana memilih pondasi tiang pancang atau pondasi mat sebagai struktur bawahnya. Menurut Bowles (1988) daya dukung tiang pancang didapatkan dari gaya gesekan yang terjadi pada luasan selimut tiang pancang dan daya dukung pada ujung tiang pancang. Dengan demikian, untuk memikul beban yang sama besarnya perencana dapat membuat variasi kedalaman tiang pancang dan jumlahnya. Perencana dapat memilih kedalaman yang kecil dengan jumlah tiang pancang yang banyak, atau memperbesar kedalaman sehingga akan mengurangi jumlah tiang pancang untuk tiap perletakan. 
Akan tetapi perbedaan kedalaman dan jumlah tiang pancang atau penggunaan pondasi mat, walaupun dirancang untuk memikul beban struktur yang sama, ternyata memberikan penurunan -- akibat deformasi tanah -- yang berbeda pada titik perleta kannya. Tavio (1996) menyebutkan akibat beban struktur tanah akan terjadi deformasi, yang sebaliknya deformasi tanah akan mempengaruhi/merubah gaya-gaya dalam pada struktur. ini berarti dengan pemilihan jenis pondasi yang berbeda diatas, akan memberikan konsekuensi pada gaya dalam yang berbeda pada struktur atasnya. Hal ini akan mengakibatkan terjadinya perbedaan penulangan pada balok induk dan kolom pada struktur tersebut.

Dengan demikian pemilihan jenis pondasi pada struktur atas yang sama akan metnberikan perbedaan pada total biayanya. Perbedaan tersebut selain berasal dari biaya pondasi yang berbeda, juga disebabkan oleh biaya struktur atas yang berbeda. Untuk itu penulis ingin membandingkan diantara perbedaan kedalaman dan jumlah tiang pancang serta penggunaan pondasi mat, alternatif mana yang akan memberikan biaya yang paling ekonomis pada gedung A Teknik Sipil ITS ini.

Dalam hal ini jenis pondasi yang dipilih adalah group tiang pancang dengan kedalaman $6 \mathrm{~m}, 9 \mathrm{~m}, 12 \mathrm{~m}$ dan $16 \mathrm{~m}$ serta pondasi mat. Jadi akan dibedakan 5 jenis pondasi yaitu pondasi mat dan 4 jenis pondasi tiang. Penentuan kedalaman tiang pancang diatas didasarkan pada panjang tiang pancang yang umumnya tersedia dipasaran.

\subsection{Permasalahan}

1. Bagaimana perencanaan berbagai alternatif pondasi yang dipilih.

2. Bagaimana perencanaan struktur atas akibat gaya dalam yang berbeda pada setiap tipe struktur sebagai akibat dari interaksi dari struktur atas dengan tanah pondasi.

3. Bagaimana perbandingan biaya total struktur atas dan bawah dari masing-masing tipe pondasi yang dipilih. Perbandingan ini untuk penentuan jenis pondasi yang mana yang lebih ekonomis.

\subsection{Batasan Masalah}

Perhitungan biaya hanya dihitung berdasarkan volume material beton, penulangan, dan biaya pemancangan saja. Belum termasuk biaya yang disebabkan oleh perbedaan durasi proyek akibat tingkat kesulitan yang berbeda pada setiap tipe struktur bawah dan atas. Perencanaan terhadap struktur atas meliputi penentuan dimensi dan penulangan lentur-geser pada kolom dan balok induknya, sedangkan perencanaan bangunan bawah meliputi penentuan dimensi dan penulangan pilecap, sloff, dan pelat mat, serta penentuan tiang pancang.

\section{TINJAUAN PUSTAKA}

\subsection{Penurunan (Settlement)}

Tanah selalu mempunyai peranan yang penting dalam mendirikan suatu konstruksi. 'Tanah merupakan pendukung dari konstruksi yang berdiri diatasnya. Penambahan beban vertikal yang diletakkan diatas suatu deposit tanah akan mengakibatkan terjadinya deformasi pada tanah tersebut. Secara umum deformasi yang terjadi dapat berupa perubahan bentuk (Distorsion), perubahan volume (Compression) atau dapat berupa gabungan dari keduanya. Total penurunan (Settlement) adalah merupakan total deformasi vertikal pada permukaan tanah akibat penambahan beban diatasnya. Seperti didirikannya suatu gedung, dibuatnya jalan, dan lain-lain.

Besar penurunan akhir dari konstruksi sebagai akibat dari memampatnya tanah di bawah pondasi konstruksi yang bersangkutan dan lamanya selang waktu yang dibutuhkan untuk memampat merupakan tujuan utama dalam menganalisa penurunan (Settlement). Untuk maksud tersebut maka perlu diketahui sebelumnya besar dan distribusi gaya-gaya luar yang bekerja pada tanah pondasi.

Penurunan (Settlement) yang terjadi pada lapisan tanah dasar akibat beban diatasnya mempunyai tiga komponen yaitu ; penurunan segera, penurunan konsolidasi dan penurunan sekunder. 


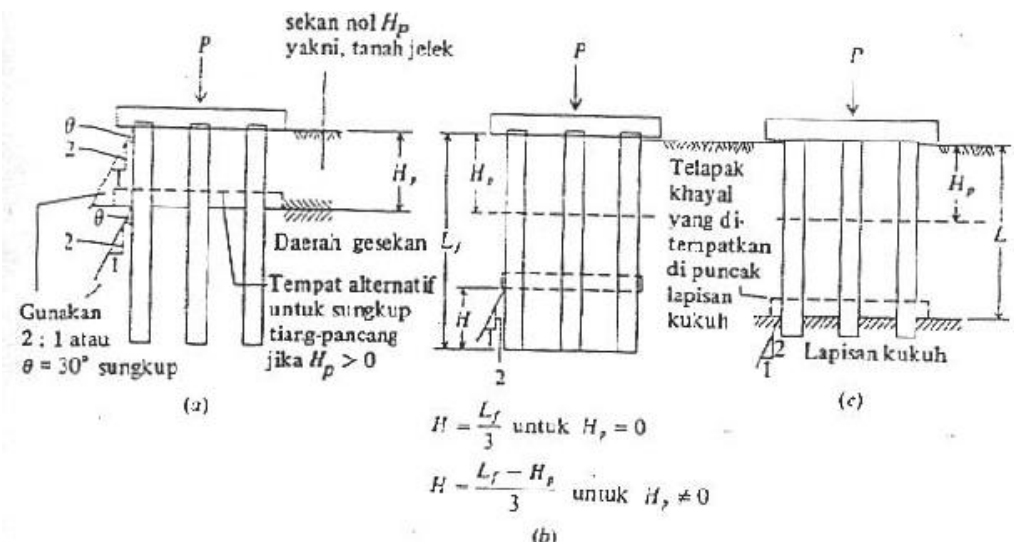

Gambar 1. Penyederhanaan distribusi tegangan kelompok tiang ke dalam tanah

$\mathrm{St}=\mathrm{Si}+\mathrm{Sc}+\mathrm{SS}$

dimana :

St = Penurunan total (Total settlement).

$\mathrm{Si}=$ Penurunan segera (Immediate settlement).

$\mathrm{Sc}=$ Penurunan konsolidasi primer (Consolidation / primary settlement)

Ss $=$ Penurunan sekunder (Secondary settlement).

\subsection{Tegangan Tanah Pada Tiang Pancang Kelompok.}

Tegangan-tegangan tanah pada lapisan tanah yang diakibatkan oleh kelompok tiang pancang seringkali diperlukan untuk membuat taksiran kekuatan atau penurunan. Bowles (1988) menyatakan tegangan-tegangan disini sangat sukar ditaksir karena beberapa alasan :

1. Pengaruh pile cap --biasanya bersentuhan langsung dengan tanah kecuali pada pile cap tanah ekspansif. Hal ini mengakibatkan tanah yang disentuh dan tiang pancang yang memikul beban berinteraksi secara tak tentu.

2. Distribusi efek gesekan sepanjang tiang pancang, umumnya tidak diketahui, karena itu beban titik juga tidak diketahui.

3. Kelebihan (overlap) tegangan dari tiangtiang pancang berdekatan sukar untuk dihitung.

4. Pengaruh pemancangan tiang pancang pada tanah yang berdekatan.

5. Efek yang bergantung pada saat konsolidasi, tixotropy, beban-beban yang berubah, dan perubahan permukaan air tanah.

Dengan mempertimbangkan semua variabel ini, maka pada prakteknya sudah umum untuk menyederhanakan perhitungan tegangan, seperti yang digambarkan dalam Gambar 1. Untuk tiang pancang gesekan ada dua hal yang dapat ditinjau. Dalam hal pertama (Gambar 1a) beban dianggap tersebar dari sebuah permukaan kaku khayal (fictitious rigid footing) yang ditempatkan pada puncak lapisan, yang memberikan tahanan gesekan pada kemiringan 2:1 (atau $\left.30^{\circ}\right)$. Untuk lapisan homogen hal ini dinyatakan dalam permukaan tanah. Dalam hal kedua, beban ditempatkan pada permukaan kaku khayal yang diletakkan L/3 dari dasar tiang pancang (kedalaman ratarata).(Gambar 1b). Penyebaran beban juga diambil pada $2: 1$ atau $30^{\circ}$. Bagi tiang pancang end bearing dalam pasir mampat atau endapan batu kerikil-pasir, permukaan kaku khayal yang ditempatkan pada deposit dimana tiang pancang melakukan penetrasi. Muatan tersebar pada kemiringan 2:1 atau $30^{\circ}$ (Gambar 1c).

Analisa ini diperlukan untuk menghindari tegangan yang berlebihan (overstressing) pada lapisan dasar. Analisa tersebut juga diperlukan untuk menghitung penurunan segera (immediate settlement) pada endapan butiran bebas atau penunman konsolidasi dalam endapan lempung. Sebuah tiang pancang kelompok dapat meneiuskan beban melalui massa tanah sedalam Lf untuk tiang pancang gesekan maupun ke 
kedalaman $\mathrm{L}$ untuk tiang pancang end bearing. Tanah yang berada pada kedalaman ini atau yang berada dibawah kedalaman ini harus mengangkut beban tanpa deformasi yang berlebihan, atau beban harus diteruskan atau ditransmisikan kelapisan yang lebih dalam.

\subsection{Interaksi antara Struktur Atas, Pondasi dan Tanah}

Sampai saat ini banyak perencana di dalam melakukan analisa pada struktur bertingkat mengikui anggapan bahwa struktur dianggap ditumpu secara sempurna diatas tanah yang tidak berdeformasi. Dalam anggapan ini, perletakan struktur atas pondasi biasanya dianggap terjepit ataupun tumpuan sendi yang tidak bergerak, sehingga dengan asumsi tersebut struktur dianggap terpisah dari pondasi maupun tanah, Tavio (1996) menyebutkan, pada kenyataannya antara struktur atas dan pondasi maupun tanah terdapat suatu interaksi dan merupakan satu kesatuan sistem yang utuh. Sebetulnya pada tanah akibat beban strukur akan terjadi deformasi, yang sebaliknya deformasi tanah akan mempengaruhi / merubah gaya-gaya dalam pada struktur.

Dengan demikian analisa struktur yang dilakukan secara terpisah akan menyebabkan perbedaan gaya dalam berbeda dengan analisa interaksi-tanah. Penggunaan analisa yang sederhana diatas sebetulnya terpaksa dilakukan dimasa lalu demi kemudahan saja karena perhitungan analisa struktur dilakukan secara manual dan belum ada program bantu semacam sofware SAP (Structure Analysis Program). Jadi, untuk perhitungan analisa struktur yang sederhana saja diperlukan waktu yang cukup lama. Akan tetapi, pada masa sekarang telah banyak tersedia program bantu semacam sofware SAP. Analisa semacam itu haruslah dikaji ulang apakah masih memenuhi atau tidak, ataukah ada batasan-batasan dalam penggunaannya.

Dengan adanya perkembangan teknologi diatas, analisa secara interaksi strukturtanah menjadi tidak terlalu sulit. Jadi semestinya pondasi harus dianalisa penurunannya akibat beban struktur, sebaliknya gaya dalam tambahan akibat adanya penurunan pondasi juga harus diperhitungkan.

\section{METODOLOGI}

Metodologi yang dilaksanakan adalah sebagai berikut ;

1. Mengumpulkan data struktur gedung dan data tanahnya.

2. Menentukan pembebanan yang diterima oleh struktur menurut Peraturan Pembebanan Indonesia (PPI) (1983), dan selanjutnya dibuat permodelan strukturnya untuk SAP90.

3. Dilakukan analisa struktur pada permodelan struktur diatas, dengan bantuan progam SAP90, sehingga didapatkan gaya-gaya untuk perencanaan pondasi tiang.

4. Merencanakan pondasi group tiang pancang dengan urutan sebagai berikut ;

- Menentukan dimensi tiang pancang yang paling ekonomis.

- Menghitung daya dukung ijin tiang pancang tunggal dari dimensi yang terpilih diatas, untuk kedalaman rencana $6,9,12$, dan $16 \mathrm{~m}$, dengan metode Nottingham dan Schmertman (1975).

- Merencanakan jumlah dan susunan tiang pancang untuk kedalaman rencana $6,9,12$, dan $16 \mathrm{~m}$.

5. Menentukan penyebaran gaya pada masing-masing group tiang pancang

6. Menentukan koefisien pegas pada group tiang pancang dengan urutan sebagai berikut ;

- Dihitung penurunan konsolidasi yang terjadi $(\Delta)$ berdasarkan gaya yang terjadi $(P)$ dan penyebaran gayanya.

- Koefisien pegas $(k)$ dapat dihitung sbb ; $\mathrm{k}=\mathrm{P} / \Delta$.

- $\quad \mathrm{k}$ yang telah didapat dipasang pada tiap perletakan, dan selanjutnya dilakukan analisa struktur dengan SAP90 --hanya menggunakan beban hidup dan beban mati-- sehingga didapatkan beban aksial (P) pada tiaptiap perletakan. Akibat beban $P$ tersebut, dihitung kembali penurunan konsolidasi yang terjadi, sehingga didapatkan $\Delta$ dan $\mathrm{k}$ yang baru, pada tiap perletakan.

- Begitu selanjutnya sehingga didapatkan harga $P$ dan $k$ yang semakin konvergen. 
- Harga $\mathrm{k}$ terakhir yang didapatkan adalah koefisien pegas pada group tiang pancang.

- Iterasi diatas dilakukan pada semua group tiang pancang kedalaman 9, 12, dan $16 \mathrm{~m}$.

7. Menentukan koefisien pegas tanah pada pondasi MAT dengan urutan sbb ;

- Menghitung penurunan rata-rata (settlement consolidation) tanah akibat beban merata yang sebanding dengan berat gedung dibagi luasan pondasi MAT. Adapun caranya adalah sbb ;

Penurunan rata-rata $=$

(Penurunan rata-rata sudut MAT +

Penurunan pada pusat MAT ) / 2

- Dilakukan analisa struktur dengan SAP90 dimana MAT foundation dimodelkan sebagai shell, yang terletak diatas pegas-pegas. Harga koefisien pegas $(k)$ ditentukan dengan cara coba-coba sehingga didapatkan penurunan rata-rata yang sama dengan penurunan rata-rata pada perhitungan settlement consolidation diatas.

8. Menentukan gaya dalam akhir yang bekerja pada masing-masing struktur akibat perbedaan jenis pondasi dengan urutan sbb ;

- Dilakukan analisa struktur untuk mendapatkan gaya dalam akibat beban mati dan akibat beban hidup dengan koefisien pegas $(k)$ yang sesuai dengan jenis pondasinya.

- Dilakukan analisa struktur akibat beban gempa dengan perletakarn dimodelkan sebagai sendi.

- Dilakukan perhitungan kombinasi gaya dalam yang terjadi pada masingmasing struktur sesuai dengan SKSNI (1991).

9. Dari gaya dalam yang didapatkan diatas, dilakukan perhitungan penulangan lentur balok, penulangan geser balok, penulangan kolom, penulangan pelat MAT, dan penulangan poer sesuai dengan SKSNI (1991).

10. Dilakukan perhitungan biaya akibat penulangan lentur balok, penulangan geser balok, penulangan koiom., penulangan pelat MAT, penulangan poer, dan biaya yang ditimbulkan oleh tiang pancang.

11. Dari hasil diatas, dilakukan perbandingan biaya pada struktur sesuai dengan pondasi masing-masing

\section{ANALISA DAN PERHITUNGAN}

\subsection{Penentuan jumlah tiang}

Penentuan jumlah tiang pancang dilakukan dengan menghitung daya dukung ijin tiang pancang tunggal $30 \times 30$ untuk kedalaman rencana $6,9,12$, dan $16 \mathrm{~m}$. Karena ukuran tiang tersebut $(30 \times 30 \mathrm{~cm})$ adalah yang paling ekonomis. Perhitungan daya dukung tersebut dilakukan pada semua data sondir S1, S2, S3, S4, S5 dan S6. Dari perhitungan diketahui Pijin untuk kedalaman $6 \mathrm{~m}=2.393$ $\mathrm{kg}$, untuk $9 \mathrm{~m}=5.198 \mathrm{~kg}$, untuk $16 \mathrm{~m}=$ $18.915 \mathrm{~kg}$, dan untuk $16 \mathrm{~m}=36.091 \mathrm{~kg}$.

Dari output SAP90 - dengan perletakan sendi - diketahui bahwa gaya aksial maksimum yang terjadi pada perletakan (dari 14 titik perletakan yang ada) adalah $229.196 \mathrm{~kg}$. Berdasarkan data-data diatas, dengan mempertimbangkan efisiensi tiang pancang group, maka dapat ditentukan jumlah dan konfigurasi tiang pancang pada perletakan. Dalam perencanaan ini spasing yang digunakan adalah 2,5D. Sebab Bowles (1988) menyebutkan bahwa spasing minimum yang dapat dipakai adalah 2D, sedang untuk gaya-gaya vertikal, spasing yang optimum adalah 2,5 sampai $3,5 \mathrm{D}$.

Tabel 1. Jumlah titik tiang tiap perletakan

\begin{tabular}{ccc}
\hline Kedalaman & Jml tiang & Keterangan \\
\hline \hline $6 \mathrm{~m}$ & $>120$ & $\left.{ }^{*}\right)$ \\
$9 \mathrm{~m}$ & 80 & $10 \times 8$ \\
$12 \mathrm{~m}$ & 20 & $5 \times 4$ \\
$16 \mathrm{~m}$ & 12 & $4 \times 3$ \\
\hline
\end{tabular}

$\left.{ }^{*}\right)$ alternatif ini dibatalkan karena secara teknis tidak bisa dilaksanakan.

Untuk selanjutnya dari konfigurasi tersebut dapat dicari nilai $\Delta$ dan $\mathrm{k}$ pada tiap tipe pondasi tersebut.

\subsection{Penentuan nilai $\mathbf{k}$ dan $\Delta$ untuk tiang group}

Hasil $\Delta$ dan $\mathrm{k}$ dianalisa terhadap data tanah titik B, sebab data tanah titik B memberikan nilai yang minimum. Harga $P=195$ ton diatas merupakan gaya yang terjadi pada salah 
satu perletakan Selanjutnya nilai k tersebut dipasang pada perletakan dan dilakukan analisa struktur dengan SAP90 sehingga didapatkan lagi harga $P$ pada tiap-tiap perletakan Harga $P$ tersebut digunakan kembali untuk menghitung $\Delta$ dan $\mathrm{k}$ Harga $\mathrm{k}$ yang didapatkan pada masing masing perletakan digunakan lagi untuk analisa struktur, yang menghasilkan kembali harga $P$. Begitu selanjutnya sehingga harga $P$ yang didapatkan relatif sama dengan harga $P$ pada iterasi sebelumnya Harga $k$ dan $P$ setelah iterasi dapat dilihat pada Tabel 2. Hasil k tsb selanjutnya digunakan untttk analisa struktur sehingga didapatkan gaya dalam pada struktur atas.
4.3. Penentuan nilai $\mathbf{k}$ dan $\Delta$ untuk MAT Beban pondasi MAT didesain berdasarkan beban gedung total dibagi dengan luas total pondasi MAT kemudian dihitung penurunannya sehingga dapat dicari nilai ' $k$ ' nya. Dari perhitungan didapatkan :

- Beban Mat q $\quad=3,8 \mathrm{t} / \mathrm{m} 2$

- Luas MAT $\quad=9,6 \times 43,2 \mathrm{~m} 2$

- Tebal $=30 \mathrm{~cm}$

- Penurunan sudut $=0,162 \mathrm{~m}$

- Penurunan pusat $\quad=0,703 \mathrm{~m}$

- Penurunan rata2 $(\Delta)=0,432 \mathrm{~m}$

- $\mathrm{k} \quad=11,212 \mathrm{t} / \mathrm{m}$

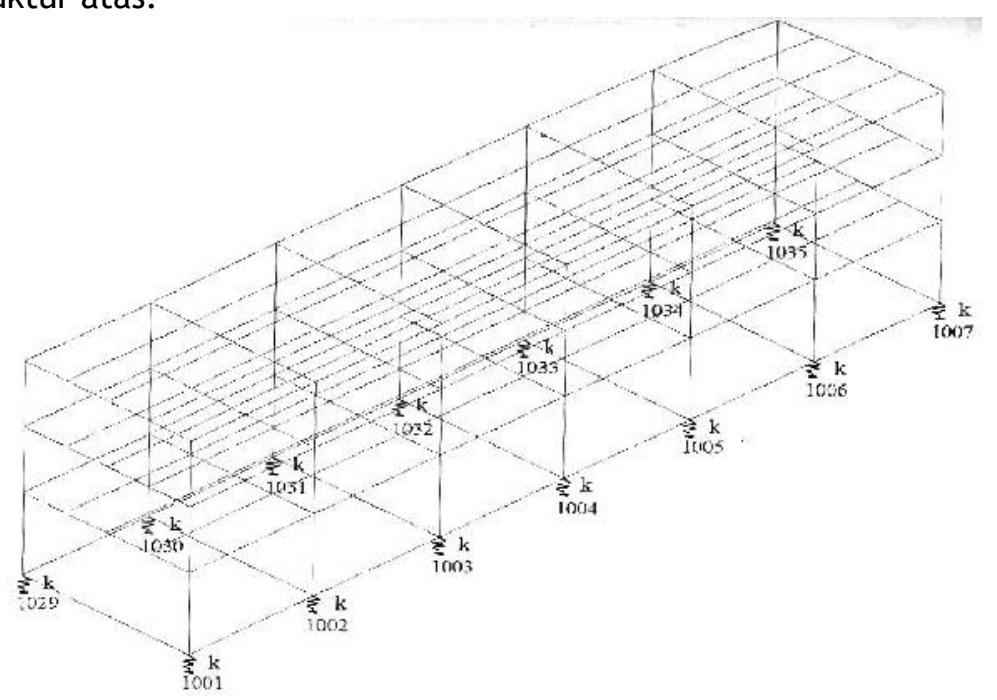

Gambar 2. Pemodelan struktur utk Pondasi Tiang Pancang Group

Tabel 2. Nilai k dan P setelah mencapai kondisi konvergen

\begin{tabular}{rccccccc}
\hline & Titik & \multicolumn{2}{c}{ Group TP s/d -9m } & \multicolumn{2}{c}{ Group TP s/d -12m } & \multicolumn{2}{c}{ Group TP s/d -16m } \\
No. & $\begin{array}{c}\text { Perle- } \\
\text { takan }\end{array}$ & $\begin{array}{c}\mathrm{k} \\
\text { (ton/m) }\end{array}$ & $\begin{array}{c}\mathrm{P} \\
\text { (ton) }\end{array}$ & $\begin{array}{c}\mathrm{k} \\
\text { (ton } / \mathrm{m})\end{array}$ & $\begin{array}{c}\mathrm{P} \\
\text { (ton) }\end{array}$ & $\begin{array}{c}\mathrm{k} \\
\text { (ton } / \mathrm{m})\end{array}$ & $\begin{array}{c}\mathrm{P} \\
\text { (ton) }\end{array}$ \\
\hline \hline 1 & 1001 & 767.01 & 160 & 296.67 & 162 & 523.81 & 156 \\
2 & 1002 & 721.43 & 181 & 305.64 & 181 & 542.40 & 181 \\
3 & 1003 & 703.30 & 194 & 311.18 & 193 & 553.47 & 196 \\
4 & 1004 & 697.52 & 199 & 313.57 & 198 & 557.56 & 201 \\
5 & 1005 & 699.18 & 197 & 313.02 & 197 & 555.82 & 199 \\
6 & 1006 & 705.75 & 192 & 310.66 & 191 & 550.77 & 192 \\
7 & 1007 & 727.30 & 177 & 305.01 & 179 & 536.90 & 174 \\
8 & 1029 & 767.82 & 159 & 296.49 & 161 & 523.64 & 156 \\
9 & 1030 & 722.03 & 180 & 305.44 & 180 & 542.20 & 181 \\
10 & 1031 & 703.95 & 193 & 310.89 & 192 & 553.15 & 196 \\
11 & 1032 & 698.41 & 198 & 313.14 & 197 & 557.00 & 201 \\
12 & 1033 & 700.03 & 196 & 312.35 & 195 & 554.81 & 198 \\
13 & 1034 & 708.70 & 190 & 309.62 & 189 & 549.00 & 190 \\
14 & 1035 & 733.13 & 174 & 303.65 & 176 & 534.00 & 170 \\
\hline
\end{tabular}




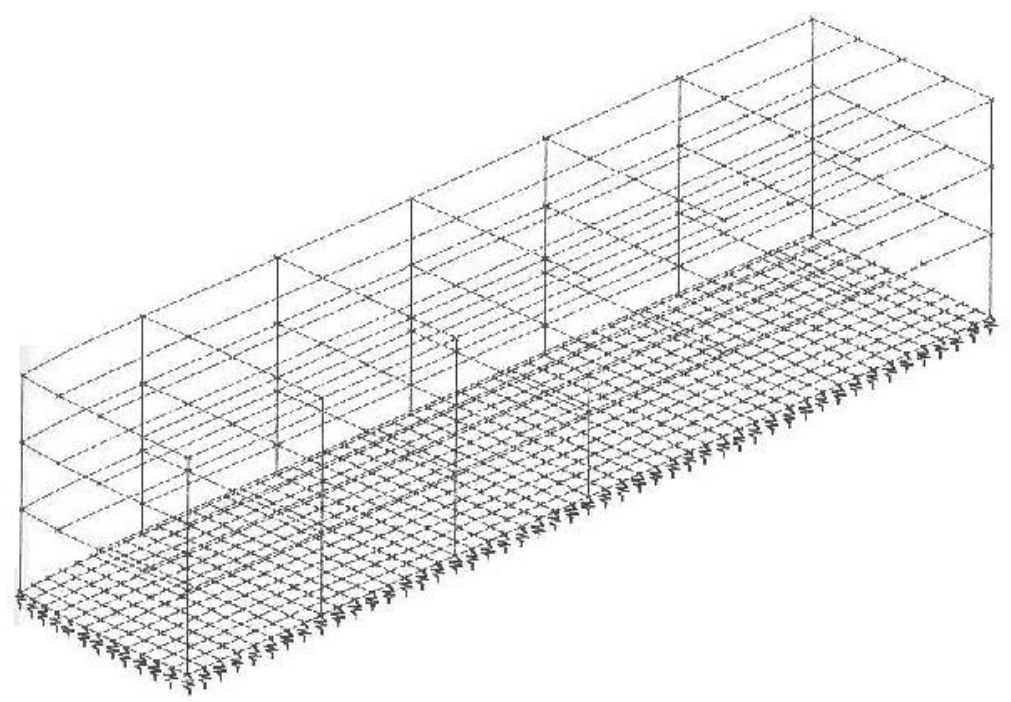

Gambar 3. Pemodelan struktur utk Pondasi MAT

Dari dari data tersebut kemudian struktur dapat dimodelkan dan dilakukan analisa struktur dan penulangannya.

\subsection{Pondasi group tiang pancang $s / d$ tanah keras $(-24 m)$}

Setelah diketahui perbandingan biaya dari struktur dengan pondasi mat dan pondasi group tiang dengan kedalaman $9 \mathrm{~m}, 12 \mathrm{~m}$, dan 16m, --yang mana terjadi deformasi pada titik perletakkannya-- maka perlu ditinjau biaya struktur apabila kedalaman pemancangan sampai pada tanah keras sehingga dianggap tidak terjadi deformasi pada titik perletakannya. Dengan demikian analisa struktur atas dilakukan dengan cara biasa, dengan menganggap perletakan sebagai jepit. Hal tersebut bisa terjadi apabila harga Pijin tiang pancang --sudah termasuk effisiensi tiang pancang group-sama dengan $3 x$ harga Pmaks.

Dari perhitungan yang telah dilakukan, group tiang pancang dianggap tidak terjadi deformasi apabila pemancangan dilakukan sampai dengan kedalaman $24 \mathrm{~m}$ dengan jumlah tiang pancang $=4$ buah untuk tiap perletakan.

Tabel 3. Jumlah titik tiang perletakan jepit

\begin{tabular}{ccc}
\hline Kedalaman & $\mathrm{Jml}$ tiang & Keterangan \\
\hline \hline $24 \mathrm{~m}$ & 4 & $2 \times 2$
\end{tabular}

Perhitungan biaya terhadap struktur atas dan sturktur bawah (pondasi) hanya didasarkan pada biaya beton, tulangan, dan pemancangan. Resume dari perhitungan biaya dapat dilihat pada Tabel 4 dan Gambar 4.

Tabel 4. Resume biaya struktur atas dan pondasi

\begin{tabular}{|c|c|c|c|c|}
\hline \multirow{2}{*}{$\begin{array}{c}\text { Jenis Pondasi } \\
\text { Pondasi MAT }\end{array}$} & \multicolumn{2}{|c|}{$\begin{array}{c}\text { Biaya } \\
\text { Struktur Atas } \\
(\times 1000) \\
\end{array}$} & \multicolumn{2}{|c|}{$\begin{array}{c}\text { Biaya } \\
\text { Pondasi } \\
(\times 1000) \\
\end{array}$} \\
\hline & $\mathrm{Rp}$ & 356,526 & $\mathrm{Rp}$ & 220,329 \\
\hline Group TP s/d -9m & Rp & 363,253 & Rp & $1,806,467$ \\
\hline Group TP s/d -12m & $\mathrm{Rp}$ & 360,799 & $\mathrm{Rp}$ & 599,786 \\
\hline Group TP s/d 16m & $\mathrm{Rp}$ & 359,563 & $\mathrm{Rp}$ & 473,270 \\
\hline Group TP s/d 24m & $\mathrm{Rp}$ & 419,243 & $\mathrm{Rp}$ & 294,420 \\
\hline
\end{tabular}

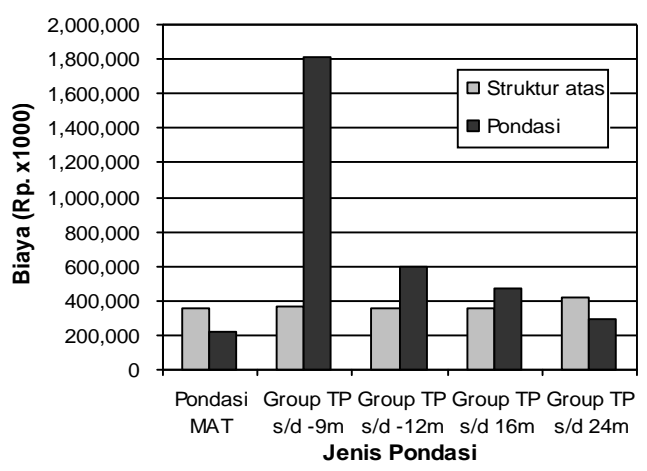

Gambar 4. Grafik perbandingan biaya struktur atas dan pondasi

\subsection{Perhitungan Biaya}




\section{KESIMPULAN}

1. Struktur dengan pondasi mat ditinjau dari pembiayaan akibat struktur atas dan' struktur bawah, memberikan biaya total yang paling ekonomis, selanjutnya diikuti dengan struktur dengan pondasi group tiang pancang $16 \mathrm{~m}, 12 \mathrm{~m}$, dan $9 \mathrm{~m}$.

2. Perbedaan jumlah total biaya banyak terutama banyak dipengaruhi oleh biaya akibat struktur bawah (pondasi).

3. Pembiayaan balok lantai 2 memberikan harga yang paling besar daripada biaya balok lantai 3 dan lantai 4 (atap). Hal ini terjadi pada semua jenis struktur, kecuali pada struktur dengan pondasi mat yang paling mahal adalah biaya balok lantai 1 (dasar) karena berfungsi sebagai pondasi.

4. Perbandingan biaya balok antara tipe struktur yang satu dengan yang lainnya menunjukkan pembiayaan akibat balok lantai 2 memberikan selisih harga yang paling besar, kemudian diikuti dengan biaya balok 3 . Sedangkan biaya balok 4 (atap) pada masing-masing jenis struktur memberikan harga yang relatif sama.

5. Pembiyaan kolom pada tipe struktur dengan pondasi mat memberikan harga yang paling besar, seterusnya diikuti dengan tipe struktur dengan pondasi group tiang pancang $9 \mathrm{~m}, 12 \mathrm{~m}$, dan $16 \mathrm{~m}$.

6. Tinjauan total biaya terhadap struktur dengan pondasi group tiang pancang kedalaman sampai dengan tanah keras (s/d -24m) memberikan harga yang lebih murah dari struktur dengan pondasi group tiang pancang kedalaman $16 \mathrm{~m}$, tetapi total biaya struktur dengan pondasi mat tetap memberikan harga yang paling ekonomis.

\section{DAFTAR ACUAN}

- Bowles,1968, Foundation Analysis and Design, New York: Mc Graw Hill Book Company.

- Das, B. M., 1988, Mekanika Tanah (Prinsip-Prinsip Rekayasa Geoteknis), Alih Bahasa : Endah. N., Mochtar, Jakarta: Erlangga.

- Departemen Pekerjaan Umum, 1991, Standar Tata Cara Perhitungan Struktur Beton untuk Bangunan Gedung SKSNI. T15-1991-03, Bandung : Yayasan LPMB.

- Departemen Pekerjaan Umum, 1983, Perencanaan Tahan Gempa Indonesia Untuk Gedung 1983, Bandung : Yayasan LPMB.

- Nottingham, L.C. and Shmertmann, J.H., 1975 , "An Investigation of Pile Capacity Design Procedures", Final Report D 629 to Florida Departement of Transportation from Departement of Civil Engineering, Florida: University of Florida.

- Wahyudi, H, 1995, Beberapa Metoda Perhitungan Daya dukung Tiang Pondasi, Surabaya: Institut Teknologi Sepuluh Nopember.

- Wang, C.K and Salmon, C.G. terj. Binsar H., 1990, Design Beton Bertulang Jilid 1 dan 2, edisi ke 4, Jakarta: Erlangga.

- Wilson dan Habibullah, A., 1989, Structural Analisys Programs 90Tm, California: Computer \& Structures INC., University Avenue Berkeley. 